\title{
MAGYARUL TANULÓ JAPÁN HALLGATÓK MEGNYILATKOZÁSAINAK - UDVARIASSÁGOT ÉRINTŐ - JELLEGZETESSÉGEI A KÉRÉS BESZÉDAKTUSÁBAN
}

\section{SitKei Dóra}

Eötvös Loránd Tudományegyetem Bölcsészettudományi Kar, Alkalmazott Nyelvészeti Doktori Program

\begin{abstract}
A jelen kutatás magyarul tanuló, s legalább felsö középhaladó szinten magyarul tudó japán anyanyelvü hallgatók köztesnyelvi kérési produktumait vizsgálja szivességkérö és jogos kérési szituációkban - az alkalmazott külsö és belső módositók tekintetében - diskurzuskiegészitö módszerrel, mely módositók fontos szerepet töltenek be egy-egy megnyilatkozás udvarias voltának megitélésében. A nyelvtanulói kéréseket összevetettem azonos szituációban adott japán anyanyelvi és magyar célnyelvi változatokkal is, s több ponton megfigyelhetö volt a nyelvtanulói produktumra ható anyanyelvi hatás, például szivességkérés esetén a kérés erejét enyhitö külső módositóknak a magyar nyelvhez képest megjelenö nagyobb száma tekintetében. Mindemellett egy célnyelvi (vagy speciális köztesnyelvi) stratégia követésének is szemtanúi lehettünk az erős célzás megjelenésével a nyelvtanulói kérésekben.
\end{abstract}

Kulcsszavak: udvariasság, a kérés beszédaktusa, köztesnyelvi pragmatika, köztesnyelvi stratégiák, japán nyelv

Nyelvészeti pragmatikai keretben - az udvariasság szemszögéből vizsgálódva - megállapítható, hogy egy diskurzus során a kérés sikerességéhez hozzájárul, ha a beszélő a megfelelő udvariassági szinten fogalmazza azt meg, amelynek különböző explicit nyelvi jelölői vannak. A nyelvtanuló idegen nyelven való megszólalásakor törekszik a célnyelvi elvárásoknak megfelelni, mindemellett különböző nyelvtanulói kommunikációs stratégiák is hatnak megszólalására az anyanyelvi kulturális háttértől való elszakadás nehézségei (Kecskés, 2006) mellett.

A nyelvtanulás kreatív folyamat, melynek során a nyelvtanuló a környezetével való interaktív kapcsolat révén létrehozza a megfigyelt szabályosságok egyfajta belső reprezentációját, amely dinamikusan változik a nyelvtanulási folyamat alatt (Corder, 1992). Ezen nyelvi rendszer megnevezésére a köztesnyelv (interlanguage, rövidítve: IL) fogalmát Selinker vezette be 1972-ben. Selinkernek a nyelvtanulói stratégiák megismerését célzó kutatási elképzelését követve egyazon szituációban három csoport megnyilatkozásait vizsgáltam: (1) magyarul tanuló japán anyanyelvü hallgatók köztesnyelvi (IL), vagyis magyar nyelvi válaszait összevetettem (2) japán anyanyelvű hallgatóktól kért japán nyelvi produktumokkal (rövidítése a továbbiakban: L1) és (3) a célnyelvi (target language, rövidítve: TL), vagyis magyar anyanyelvü hallgatóktól kapott magyar nyelvi anyaggal, majd megfigyeléseket lehetett tenni a nyelvtanulók udvariassági nyelvhasználatára, illetve a vele összefüggésben lévő kommunikációs stratégiáikra vonatkozóan - a pragmatikai kutatások általános keretein belül (l. például Szili, 2004).

\section{Anyag és módszer}

A jelen kutatás során magyarul tanuló japán hallgatók magyar megnyilatkozásait vizsgáltam kérdőívjellegű ún. nyílt végű diskurzuskiegésztő teszttel $(\mathrm{DCT})^{1}$, amely-

\footnotetext{
1 A DCT a köztesnyelvi pragmatikai kutatások egyik fö eszköze, a rögzített szociolingvisztikai tényezők alapján ideális módszer a kontrasztív vizsgálatokhoz (Beebe és
} 
ben öt $(3+2)$, kérésre vonatkozó szituáció szerepelt, melyek leírása tartalmazta azokat a szociopragmatikai (vertikális/hatalmi és horizontális/familiáris interperszonális) és beszédaktus-specifikus (a kérés szívességkérő, illetve jogos jellegére vontakozó) tényezőket, amelyeknek hatása lehet a megnyilatkozásokra. Három adatközlőcsoporttal ${ }^{2}$ dolgoztam, a kérdőívre egyfelől (1) magyarul tanuló és legalább B1-es szinten tudó japán anyanyelvű hallgatóktól (35 fö) kaptam magyar nyelvű válaszokat (IL) magyar és zárójelben angol nyelven megadott kérdőívre, amelyhez kontrollcsoportként (2) japán anyanyelvü hallgatóktól (25 fó) japán nyelvű válaszokat (L1) kaptam a kérdőív japán nyelvű változatára, emellett (3) magyar anyanyelvű hallgatóktól (40 fö) kértem magyar nyelvű válaszokat (TL) a magyarul szövegezett kérdőívre. A köztesnyelvi válaszolók papíralapon, a kontrollcsoportok adatközlői pedig interneten töltötték ki a kérdőívet.

Az alábbi szituációkra válaszoltak a kutatásban résztvevők:

a) „Egy automata mellett vagy, szeretnél venni egy gyümölcslét az automatából, de csak papírpénzed van, szeretnéd felváltani fémpénzre. Kérdezd meg egy egyetemi hallgatótól, hogy fel tud-e váltani egy papírpénzt fémpénzre."

Cummings, 1996). A kutatásban részt vevő azt írja le, amit gondol, hogy mondana (Babbie, 1998), viszont nem biztos, hogy éles szituációban is ezt mondaná, a teszt nem tudja érzékeltetni a beszélgetésben részt vevők közötti interakció pszichoszociális dinamikáját (Beebe és Cummings, 1996). A jelen vizsgálati szakaszban megfelelő számunkra megismerni azon köztesnyelvi megnyilatkozásokat, amelyet a nyelvtanuló a legmegfelelőbbnek gondol az adott szituációban attitűdje, nyelvtudása, illetve célnyelvi ismeretei alapján (Rose és Kwai-Fun, 2001).

2 Az adatközlők a következő felsőoktatási intézmények hallgatói voltak: a magyarul tanuló japán hallgatók az Oszakai Egyetem Magyar szakának, az ELTE MID tanszékének, illetve a Balassi Intézet hallgatói voltak a 2016/2017-es tanévben. A magyar anyanyelvủ hallgatók az ELTE BTK, PPK és a SZIE GTK, a japán anyanyelvü adatközlők a Chiba Egyetem és a Josai International University hallgatói közül kerültek ki. Mindenkinek, aki segített elérni az adatközlőket, illetve az adatközlőknek köszönöm a segítségét. b) „Ugyanebben a helyzetben, akit megkérdezel, 5 évvel fiatalabb, mint te."

c) „Ugyanebben a helyzetben, akit megkérdezel, 10 évvel idősebb, mint te."

d) „Kölcsönadtál egy könyvet egy osztálytársadnak és szeretnéd visszakérni. Mit mondasz?"

e) „Kölcsönadtál egy könyvet a húgodnak és szeretnéd visszakérni. Mit mondasz?"

A kapott megnyilatkozásokat a BlumKulka-Olshtain-féle rendszer szerint vizsgáltam, azon belül pedig a külső és a belső módosítók (Blum-Kulka és Olshtain, 1984) használatának jellegzetességeit vetettem öszsze a három vizsgált csoport között. Ezen módosítók rendszere egy eszköztárat nyújt a beszélő számára ahhoz, hogy beállítsa azt az udvariassági szintet, amelyet megfelelőnek gondol az adott szituációban. Mindemellett a megnyilatkozásokat besoroltam a direktségiindirektségi skálán elhelyezett kérésstratégiák rendszere szerint is, amely rendszer alapját részben az említett belső módosítók megjelenése, kombinációja adja. Majd a japán nyelvre általánosságban jellemzőnek mondott, a vizsgálat során beazonosított legindirektebb kérésstratégia, az erős célzás relatív gyakorisági értékeit néztem meg a vizsgált csoportokban a beszédszituációk szerint.

A nyelvtanulók megnyilatkozásait összehasonlítva a kontrollcsoportok válaszaival a vizsgált szempontok mentén, többféle kommunikációs stratégiát fedezhetünk fel.

\section{Az udvariasságról}

Mindenkinek van egy elképzelése arról, hogy milyen az udvarias viselkedés, vagy egy udvarias megnyilatkozás. Nézzük meg, hogy nyelvészeti pragmatikai keretben - a teljesség igénye nélkül -, időrendben haladva milyen udvariassági megközelítések fogalmazódtak meg.

Lakoff szerint az udvariasság csökkenti a súrlódást a társas kapcsolatokban; minél indirektebben fejezzük ki magukat - alapjában véve - annál udvariasabbak vagyunk (Lakoff, 1973). Leech-nél (1983) az udvariasság a konfliktus elkerülésében játszik szerepet. (Mind 
Magyarultanulójapánhallgatókmegnyilatkozásainak-udvariasságotérintő-jellegzetességeiakérésbeszédaktusában

Leech, mind Brown-Levinson megemlítik, hogy a fokozott indirektség eredményezhet udvariatlanságot [Leech, 1983; Brown és Levinson, 1987].) Watts (1989) a helyénvaló - udvarias - udvariatlan viselkedés felosztásában közelíti meg az udvariasság fogalmát, a helyénvaló jelöletlen - sokszor ez jelzi helyénvalóságát, a jelölt: udvarias vagy udvariatlan/ nem helyénvaló. Fräser és Nolan (1981) az udvariasságot egyfajta társalgási szerződés betartásához hasonlítja, Holmes (1995) szerint pedig az udvariasság mások irányába történő pozitív viselkedésként, hozzáfordulásként jelenik meg. Kádár és Haugh (2013) kiemelik az udvariasság társadalmi gyakorlat jellegét.

Eelen udvariassági modellje (2001) szerint nemcsak a beszélői szándék számít, hanem az udvariasság megítélésének ugyanolyan mértékben részese kell hogy legyen a hallgatói, illetve az interakciót megfigyelők részéről történő értelmezés, illetve értékelés is.

\section{A külső és a belső módosítók}

Nyelvészeti pragmatikai modellként leegyszerűsítve, a társas interakciók során a beszélő megnyilatkozást „címez” a hallgatónak - valamely beszédszándékának megvalósítása céljából (Gordon és Lakoff, 1975). Ezen célt követve különböző eszközökkel élhet, például külső vagy belső módosítókat (Blum-Kulka és Olshtain, 1984) alkalmazhat. Ezen módosítók az adott beszédszándék, például a kérés kifejezésének a másikra gyakorolt negatív hatását enyhíthetik, ekkor a kérést udvariassá teszik azért, hogy ne utasítsa el a hallgató a teljesítését, vagy a negatív hatással kevésbé törődve például kiemelhetik a kérés fontosságát - így biztosítandó a kérés sikerességét (Blum-Kulka és Olshtain, 1984; Trosborg, 1995). A tanulmány során az enyhítő elemekkel foglalkozom.

\section{A külsö módosítók}

A külső módosítók, a támogató elemek - a kérés kontextusának alkotórészeként - közvetetten segítik a beszédszándék, a sikeres kérés megvalósítását (Blum-Kulka és Olshtain, 1984).
Jelen kutatás során a következő enyhítő külső módosítókkal lehetett találkozni a vizsgált anyagban: (1) figyelemfelkeltő elem (a megnyilatkozásokban az elnézéskérés fordult elő, a japán nyelvű elnézéskéréshez 1 . Hidasi, 2017), (2) felkészítő elem, (3) a háttér megadása, (4) a szerénység verbális kifejezése. Mind a felkészítő elem, mind a háttér megadása sejteti a hallgatóval, hogy kéréssel fog hozzá fordulni a beszélő. A háttér megadása mindazonáltal számos esetben a kérés kifejezése után következett mindhárom vizsgált csoportban, mintegy utólag egyfajta további ráhatást gyakorolva a hallgatóra.

(1) IL a: Elnézést (figyelemfelkeltő elem), szeretnék venni egy gyümölcslét (felkészítő elem), de nekem csak papirpénzem van (háttér megadása). Felválthatsz pénzt nekem? ${ }^{3}$

(2) L1 a: すいません、今紙幣しかなく て、飲み物を買いたいのですが、よろし かったら小銭と両替してもらっても良い でしようか? Suimasen, ima shihei shika nakute, nomimono wo kaitiai-no-desu ga, yoroshikattara kozeni to ryōgae shitemorattemo yoi-deshōka?4 'Elnézést (figyelemfelkeltő elem), most csak papírpénzem van (háttér megadása), szeretnék innivalót venni (felkészítő elem)(de) ${ }^{5}$, ha jó [ötletnek tartja] (szerénység kifejezése) ${ }^{6}$, fel tudná-e váltani aprópénzre? ${ }^{7}$

\section{A belső módosítók}

A belső módosítók a komplex kérésstratégián belül - a kérést expliciten kifejező megnyilatkozás részeként - fejtik ki hatásu-

${ }^{3}$ Minden példaként felhozott mondat az adatközlők által megadott formában kerül idézésre.

4 A japán nyelvű megnyilatkozások latin betűs átírása a Hepburn-féle átírási rendszert követi.

5 A "ga" partikula szó szerinti jelentése: 'de', viszont nem megszorító utótagú ellentétet fejez ki, hanem udvariasságot jelöl.

${ }^{6} \mathrm{Ez}$ a mondatrész konvencionálisan rögzült része az udvarias kérésstratégiának.

7 A japán nyelvről magyarra történő fordítások a tanulmányban a saját fordításaim, melynek során - a lehetőségekhez mérten - a szó szerinti vagy ahhoz közeli fordításra törekedtem. - S. D. 
kat, közvetlenül segítik a beszédszándék, a sikeres kérés megvalósítását (Blum-Kulka és Olshtain, 1984; Blum-Kulka, 1985).

A vizsgált anyagban a következő enyhítő belső módosítókkal lehetett találkozni: (1) lexikai elem, azon belül: udvariasságjelölő (például „legyen szíves”), hezitálást kifejező elem (például „esetleg”), a másik aktuális lehetőségei iránti érdeklődés (a „véletlenül” határozószó használata), homályosító (például a vala- előtagú határozatlan névmások), a teljesítés határidejének kitolását kifejező elem (például a jövőre utaló „majd”), (2) szintaktikai elem, azon belül: magázás, feltételes mód, feltételes mellékmondat (feltételes móddal vagy anélkül), kérdő mondat (tagadással vagy anélkül), hatóigeképző, a lehetőség kifejezése egyéb módokon (pl. „Van lehetősége, ..."), tud segédige - képesség kifejezése, illetve ezen elemek kombinációi.

(3) IL c: Legyen szives (udvariasságjelölő) váltani papírpénzt fémpénzre.

(4) IL c: Elnézést! Tudna (képesség kifejezése + feltételes mód + kérdő mondat) váltani ezt fémpénzre?

(5) IL c: Fel tud-e váltani? (képesség kifejezése + kérdő mondat)

(6) L1 c: 自動販売機で飲み物を買いた いのですが、紙幣を両替してもらうことは 可能ですか?Jidōhanbaiki de nomimono wo kaitai-no-desu-ga, shihei wo ryōgaeshite moraukoto wa kanō desuka? 'Az automatából szeretnék italt venni, de (udvariasságjelölő, 1. 5. lábjegyzet) van lehetősége (lehetőség kifejezése + kérdő mondat), papírpénzt felváltani?'

\section{A módosítók összefoglalása}

\begin{tabular}{|c|c|c|c|c|c|c|}
\hline \multirow{2}{*}{} & \multicolumn{3}{|c|}{ Külső módositók } & \multicolumn{3}{c|}{ Belső módositók } \\
\cline { 2 - 7 } & $\mathrm{L} 1$ & $\mathrm{IL}$ & $\mathrm{TL}$ & $\mathrm{L} 1$ & $\mathrm{IL}$ & $\mathrm{TL}$ \\
\hline $\mathrm{a}$ & 2,18 & 1,27 & 1 & 2,94 & 1,81 & 3,2 \\
\hline $\mathrm{b}$ & 2,06 & 1,08 & 1 & 2,9 & 1,7 & 3,07 \\
\hline $\mathrm{c}$ & 2,41 & 1,24 & 1,21 & 3,53 & 1,92 & 3,4 \\
\hline $\mathrm{d}$ & 0,74 & 0,46 & 1 & 1,82 & 1,35 & 2,33 \\
\hline e & 0,18 & 0,11 & 0,73 & 0,29 & 0,41 & 0,87 \\
\hline
\end{tabular}

1. táblázat: A módosítók megnyilatkozásonkénti átlaga beszélői csoportonként és szituációnként
A táblázatban szereplő átlagok nem fejezik ki teljes mértékben az adott csoportnál megjelenő udvariassági szintet a módosítók tekintetében, azon okból, hogy a különböző módosítók az elemzésben egyenértékű módosítókként szerepelnek, de a másik fél különböző erősségűnek érzékelheti, értékelheti őket (l. Eelen udvariassági modelljéről $A z$ udvariasságról c. fejezetben). Mindemellett a japán anyanyelvi (L1) megnyilatkozások módosítókategóriái teljes mértékben nem feleltethetők meg a magyar nyelv alapján megadottaknak; viszont az adott beszélői csoporton belül konzisztens eredmények születtek, így az egyes szituációk közötti udvariassági különbségekre vonatkozóan lehet következtetésekkel élni.

A belső módosítók TL-szintet megközelítő nyelvtanulói használata körülbelül $\mathrm{C} 1-$ C2-es szinten valósulhat meg, viszont a kitöltők 95\%-a B1-B2-es szinten tudott magyarul, így a nyelvtanulói kompetenciával magyarázható a relatív alacsony belső módosítói arány az általuk megadott megnyilatkozásokban. Mindazonáltal a nyelvtanuló csoportban is követhető, hogy figyelembe vették a beszélők a változó szociopragmatikai tényezőket (a beszédpartner életkori, hierarchiabeli jellemzőit, illetve ismeretlen - az első szituációkörben, vagy ismerős személy-e a hallgató - a második szituációkörben) és a kérések szívességkérő vagy jogos jellegét.

$\mathrm{Az}$ „a”- „, $\mathrm{b}$ ”-„c" szituációk esetében a kérést szívességkérés-közelinek tekinthetjük, más megközelítésből úgy is fogalmazhatunk, hogy a kérés kirovó jellege alacsony (Blum-Kulka és Olshtain, 1984), amelyhez képest a "d” és az „e” szituációkban nagyobb a kirovó jelleg mértéke, ekkor jogos kérésről van szó. Mindez tükröződik a módosítók mennyiségében is: szívességkérés esetén - a jogos kéréshez képest - több enyhítő módosítóval él a beszélő alacsony fokú kirovó szerepének megfelelően (l. még Bándli és Maróti, 2003).

A táblázatban bemutatott csoportátlagok alapján a következő megfigyeléseket tehetjük. A szívességkérés-közeli első szituációkör esetén a japán anyanyelvű adatközlők mindkét csoportban - a magyar anyanyelvü adatköz- 
Magyarultanulójapánhallgatókmegnyilatkozásainak-udvariasságotérintő-jellegzetességeiakérésbeszédaktusában

lőkhöz képest - több külső módosítót alkalmaztak; a második szituációkörben, a magasabb fokú kirovó szerep (jogos kérés) esetén pedig kevesebbet. A belső módosítók terén figyelembe véve a korábban említett vizsgálati nehézségeket - az egyes beszélői csoportokban lehetett követni a módosítók szituációnkénti változását a szociopragmatikai tényezők és a kérés jogosságának függvényében. Jogos kérés esetén a magyar nyelvhez képest japán-, illetve köztesnyelven kevesebb enyhítő módosítót alkalmaztak a beszélők (szembetűnő a beszélői csoportok közötti különbség az utolsó szituációban, ahol a beszélő a húgától kéri vissza a könyvet).

\section{(In)direktség a kérésstratégiában}

A beszélő az alkalmazott módosítók segítségével „beállítja” a megnyilatkozások direktségének mértékét. Egyfajta direktségi sorrendben a következő kérésstratégiákat lehetett megfigyelni a vizsgált anyagban (a bemutatott rendszerhez kiindulópontként szolgált: Blum-Kulka és Olshtain, 1984):

Direktnek tekinthető kérésstratégiák:

1. Felszólító mód:

(7) IL e: Add vissza a könyvet!

(8) L1 e: 本返して! Hon kaeshite!'Add viszsza a könyvet!'

Célnyelven nem volt példa erre a kérésstratégiára.

2. A „kér” (performatív) ige belső módosító nélkül szerepel a mondatban:

(9) IL a: Bocsanat, azt kérem hogy fel tud-e váltani egy papír pénzt fémpénzre.

3. A „kér” ige belső módosítóval szerepel a mondatban:

(10) IL a: Elnézést. Kérhetem felváltani ezt a fémpénzre?

4. Szándékkifejezés: az „akar” és a „szeretne” ige szerepel a mondatban - belső módosítóval vagy anélkül:

(11) IL a: Elnézést, akarok fel váltani egy papir pénzt fémpénzre.
(12) IL d: Szeretnék visszakérni a könyvet.

Célnyelven nem volt példa erre a kategóriára, japán nyelven (L1) csak a külső módosítókhoz tartozó háttérmegadásnál találkozhattunk vele:

(13) L1 b: 自動販売機で飲み物を買いた いんですけど、... Jidōhanbaiki de nomimono wo kaitai-n-desu-kedo, ... 'Szeretnék az automatából italt venni, (de)....'

Indirektnek tekinthető stratégiák:

5. Az ige feltételes módban - kérdő mondatban szerepel:

(14) L1 a,b: Van egy kérésem. Tudnád felváltani egy papír pénzt fémpénzre? Automatából szeretnék venni, de nincs fémpénz.

6. Erős célzás (ekkor nem találkozhatunk explicit kéréskifejezéssel, mindemellett az elhangzott utalásból érti a hallgató, hogy kérésről van szó; az utalás általában kapcsolódik a kérés tárgyához, vö. Blum-Kulka és Olshtain, 1984):

(15) IL a,b,c: Van apród?

(16) TL a,b: nincs nálad 500 forintnyi apró véletlenül?

(17) IL d,e: Elolvastad a könyvemet?

(18) IL e: Hol van a könyvem? Szüksegem van rá.

Egy kérésstratégia-típust kiválasztva, nézzük meg az erős célzás relatív gyakorisági értékeit a beszélői csoportok és a szituációk bontásában.

\begin{tabular}{|c|c|c|c|}
\hline & $\mathrm{L} 1$ & $\mathrm{IL}$ & $\mathrm{TL}$ \\
\hline $\mathrm{a}$ & $0 \%$ & $6 \%$ & $5 \%$ \\
\hline $\mathrm{b}$ & $0 \%$ & $6 \%$ & $5 \%$ \\
\hline $\mathrm{c}$ & $0 \%$ & $3 \%$ & $0 \%$ \\
\hline $\mathrm{d}$ & $0 \%$ & $11 \%$ & $5 \%$ \\
\hline $\mathrm{e}$ & $0 \%$ & $3 \%$ & $5 \%$ \\
\hline
\end{tabular}

2. táblázat: Az erős célzás relatív gyakorisági értékei a beszélői csoportokban szituációnként

A japán (L1) válaszokban nem lehetett erős célzással találkozni, a célnyelvhez képest pedig általában kismértékben magasabb relatív gyakorisági értékeket mutatnak a nyelvtanulói produktumok releváns értékei. A köztesnyelvi válaszokban tanulságos követ- 
ni, hogy milyen mértékben változik a célzás használata, például a „C” szituációban, ahol a szociopragmatikai tényezők alapján a legudvariasabban nyilatkoznak meg a beszélők: alacsonyabb az erős célzás gyakorisága az első körös hasonló szituációkhoz képest, illetve a húggal való diskurzusban, az „e” szituációban a legalacsonyabb az érték, az előbbi esetben a beszélő is érzi, hogy a célzás nem feltétlenül a legudvariasabb eszköz (l. Az udvariasságról c. fejezetben), az „e” szituációban pedig közeli rokonnal való diskurzus esetén nincs szükség indirekten fogalmazni, célzással élni.

\section{Nyelvtanulói kommunikációs stratégiák}

A vizsgált anyagban jól megfigyelhető a nyelvtanulói produktumokkal (IL) szó szerinti fordításban megegyező japán nyelvü (L1) megnyilatkozások előfordulása, amelyek egyúttal eltérnek a célnyelvi (TL) megnyilatkozásoktól, vagyis feltételezhető a negatív anyanyelvi transzfer (1. Beebe, Takahashi és Uliss-Weltz, 1990). Az anyanyelvi transzfer során a nyelvtanuló egyfajta anyanyelvi sémarendszert transzferál át köztesnyelvi megnyilatkozásába, - a kulturálisan meghatározott - nyelvi és társas (szociális) viselkedésre vonatkozó háttértudása alapján (Carrell 1983-as sémateóriája alapján Guido, 2008)

A nyelvtanulónak nehézséget jelenthet az anyanyelvéhez képest más módosítóarányokat alkalmazni. Ahogy láttuk a japán L1-hez képest magyar nyelven kevésbé halmozzuk a külső módosítókat kérésünk megtámogatása céljából, amelynek megvalósítása problémát jelenthet a nyelvtanuló számára azon félelme miatt, nehogy átlépje az udvariasság-udvariatlanság határát, ami visszatarthatja a kívánt mértékű módosítócsökkentés végrehajtásában.

A direktségi-indirektségi skálán elhelyezett kérésstratégiák egyike, az erős célzás jelenlétét a vizsgált anyagban megnézve, a nyelvtanuló ekkor olyan formával él, amelyre nincs példa anyanyelvén az adott szituációban, vagyis el tudott szakadni az anyanyelvi mintától. Mindemellett esetünkben találkozhatunk ezen nyelvi formával célnyelven is. A sikeres köztesnyelvi beszédstratégia-választás elismerését meghagyva, említsük meg Trosborg (1995) elméletét, amely szerint az erős célzás használatának oka a nyelvtanuló bizonytalanságában rejlik, hogy milyen konvencionálisan rögzült kifejezést szükséges használnia a tanult idegen nyelven, emiatt azt kiváltandó, kreatív módon célzást használ.

\section{Zárógondolatok}

Általánosságban elmondható, hogy a bemutatott külső és belső módosítók udvariasabbá teszik a kérést, s így hozzájárulnak ahhoz, hogy a másik fél teljesítse. A szituációkban megjelenő különböző szociopragmatikai tényezők és a kérések szívességkérés-közeli, vagy jogos jellege közötti különbségek lehetőséget adtak arra, hogy megfigyeléseket tegyünk a nyelvtanulók udvariassági választásaira vonatkozóan. A nyelvtanulónak nehéz elszakadnia az anyanyelvi mintáktól (például az anyanyelvéhez képest nehéz számára kevesebb külső módosítót használni köztesnyelven), mindemellett egyéb kommunikációs stratégiák (például Trosborg elmélete szerint a célzáshasználat a konvencionális kifejezésekben való bizonytalanságból adódóan) is hathatnak a köztesnyelvi megnyilatkozás létrejötte során.

\section{Felhasznált irodalom}

Babbie, E. R. (1998): The practice of social research (8th ed.). Wadsworth, Belmont.

Bándli Judit és Maróti Orsolya (2003): Kultúra és nyelvi viselkedés. Japán diákok kérési és visszautasítási stratégiái magyar nyelven. Hungarológiai Évkönyv, 4. 1. sz., 137-152.

Beebe, L. M. \& Cummings, M. C. (1996): Natural speech act versus written questionnaire data: How data collection method affects speech act performance. In: Gass, S. M. és Neu, J. (szerk.): Speech Acts across Cultures. Mouton de Gruyter, Berlin. 65-86.

Beebe, L. M., Takahashi, T. \& Uliss-Weltz, R. (1990): Pragmatic transfer in ESL refusals. In: Scarcella, R. C., Andersen, E. S. és Krashen, 
Magyarultanulójapánhallgatókmegnyilatkozásainak-udvariasságotérintő-jellegzetességeiakérésbeszédaktusában

S. D. (szerk.) Developing communicative competence in a second language. Newbury House, New York. 55-73.

https://doi.org/10.1515/9783110219289.1.65

Blum-Kulka, S. (1985): Modifiers as Indicating Devices: The Case of Requests. Theoretical Linguistics, 12. 1. sz., 213-230.

https://doi.org/10.1515/thli.1985.12.s1.213

Blum-Kulka, S. \& Olshtain, E. (1984): Requests and Apologies: A Cross-Cultural Study of Speech Act Realization Patterns (CCSARP). Applied Linguistics, 5. 3. sz.,196-213. https://doi.org/10.1093/applin/5.3.196

Brown, P. \& Levinson, S. C. (1987): Politeness. Some universals in language use. Cambridge University Press, Cambridge. https://doi.org/10.1017/CBO9780511813085

Carrell, P. L. (1983): Some Issues in Studying the Role of Schemata, or Background Knowledge, in Second Language Comprehension. Reading in a Foreign Language, 1. 2. sz., 81-92.

Corder, S. P. (1992): A Role for the Mother Tongue. In: Gass, Susan M. és Selinker, Larry (szerk.): Language Transfer in Language Learning. John Benjamin Publishing Company, Amsterdam-Philadelphia, 18-31. https://doi.org/10.1075/lald.5.04cor

Eelen, G. (2001): A Critique of Politeness Theories. St. Jerome, Manchester.

Fräser, B. és Nolan, W. (1981): The association of deference with linguistic form. In: Walters, J. (szerk.) The Sociolinguistics of Deference $\mathcal{E}$ Politeness. Mouton, The Hague, 93-111. https://doi.org/10.1515/ijsl.1981.27.93

Gordon, D. és Lakoff, G. (1975): Conversational Postulates. In: Cole, P. és Morgan, J. L. (szerk.) Syntax and Semantics 3: Speech acts. Academic Press, New York, 83-106.

Guido, M. G. (2008): English as a lingua franca in cross-cultural immigration domains. Peter Lang, Bern. https://doi.org/10.3726/978-3-0351-0664-0

Hidasi Judit (2017): Az udvariasság relativitásáról - japán példák alapján. In: Balázs Géza és Pölcz Ádám (szerk.) Udvariasság. (2. bőv. kiadás) Magyar Szemiotikai Társaság, Budapest, 221-232.

Holmes, J. (1995): Women, Men, and Politeness. Longman, London.

Kádár, D. Z. \& Haugh, M. (2013): Understanding Politeness. Cambridge University Press, Cambridge. 57-80.

https://doi.org/10.1017/CBO9781139382717

Kecskés, I. (2006): On My Mind: Thoughts about Salience, Context, and Figurative Language from a Second Language Perspective. Second Language Research, 22. 2. sz. 219-237. https://doi.org/10.1191/0267658306sr266ra

Lakoff, R. T. (1973): The logic of politeness: or, minding your p's and q's. In: Corum, C., Smith-Stark, T. C. \& Weiser, A. (eds.) Proceedings of the ninth regional meeting of the Chicago Linguistic Society. University of Chicago Press, Chicago, 292-305.

Leech, G. N. (1983): Principles of Pragmatics. Longman, London.

Rose, K. R. \& Kwai-Fun, C. N. (2001): Inductive and deductive teaching of compliments and compliment responses. In: Rose, K. R. és Kasper, G. (szerk.) Pragmatics in language teaching. Cambridge University Press, Cambridge. $145-170$. https://doi.org/10.1017/CBO9781139524797.013

Selinker, L. (1972): Interlanguage. International Review of Applied Linguistics, 10. 3. sz., 209-231.

Szili Katalin (2004): Tetté vált szavak. A beszédaktusok elmélete és gyakorlata. Tinta, Budapest.

Trosborg, A. (1995): Interlanguage Pragmatics: Requests, Complaints and Apologies. Mouton de Gruyter, Berlin.

Watts, R. J. (1989): Relevance and relational work: linguistic politeness as politic behavior. Multilingua, 8. 2-3. sz., 131-167. https://doi.org/10.1515/9783110885286 


\section{Politeness characteristics of Japanese L1/Hungarian L2 students' utterances in the speech act of requesting}

Using data gathered through the discourse completion test, the present study investigates interlanguage requests by Hungarian L2 (at higher intermediate level)/Japanese L1 students in asking for favours and making legitimate requests with respect to external and internal modifications. These modifications have an important role in the evaluation of the politeness of the utterances. During research, the interlanguage requests were compared to their counterparts in the mother tongue and the target language. As a result, we were able to observe the influence of the mother tongue, eg. when the language learner used more external modifications compared to in the target language, when asking favours. However, when given strong hints, the students followed a target language strategy (or a strategy that can be regarded as a specific interlanguage strategy).

Keywords: politeness, the speech act of requesting, interlanguage pragmatics, interlanguage strategies, Japanese language

Sitkei Dóra (2019): Magyarul tanuló japán hallgatók megnyilatkozásainak - udvariasságot érintő jellegzetességei a kérés beszédaktusában. Gyermeknevelés, 7. 1. sz., 83-90. 